\title{
Choroidal thickness changes in connective tissue diseases
}

\section{Bağ dokusu hastalıklarında koroidal kalınlık değişikleri}

\author{
ErhanYUMUŞAK ${ }^{1 a}$, Murat KÜÇÜKEVCiLIOĞLU², Gökhan ÖZGE², Hakan DURUKAN², Oktay DiNER², Önder AYYILDIZ²
}

'Kırıkkale University School of Medicine, Department of Ophthalmology, Kırıkkale, ${ }^{2}$ Gülhane Military Medical Academy, Department of Ophthalmology, Ankara, TURKEY

\section{ABSTRACT}

Aim: The aim of this study is to evaluate the choroidal thickness (CT) changes in connective tissue disease (CTD) using spectral domain optical coherence tomography (SD OCT) with enhanced depth imaging (EDI).

Material and Methods: In this prospective clinical study, we included 34 subjects who were diagnosed as CTD in remission for at least 3 months, and age and gender matched 30 healthy controls. Central macular thickness (CMT), subfoveal CT, and CT at nasal (N) and temporal (T) distances of $500 \mu \mathrm{m}$ (N500 and T500, respectively) and $1500 \mu \mathrm{m}$ (N500 and T1500, respectively) from the central fovea were measured by EDI OCT.

Results: The mean CMT of the patient group $(219.2 \mu \mathrm{m})$ was thinner compared to the control group $(225.5 \mu \mathrm{m})$, but the difference was not statistically significant $(P=0.2)$. At the same time, mean $C T$ values were thinner at all measure points in the CTD subjects. The mean subfoveal CT, N500, N1500, T500 and T1500 were not significantly different in comparison to controls (all $\mathrm{P}>0.05$ ).

Conclusion: Although our results did not reach statistical significance, we found that choroidal tissue was thinner in patients with CTD .

Keywords: Optical coherence tomography, eye diseases, connective tissue disease, choroidal disease, clinical study

Corresponding Author a: ErhanYumusak, MD, Kırıkkale Üniversitesi Tıp Fakültesi Hastanesi, Yenişehir Mahallesi, 71450, Yahşihan, 


\section{öz}

Amaç: Çalışmanın amacı bağ dokusu hastalıklarında (BDH) koroid kalınlığı (KK) değişikliklerinin Spektral Domein optik koherens tomografi (SD OKT) kullanılarak değerlendirilmesidir.

Gereç ve Yöntemler: Bu prospektif klinik çalışmada, en az 3 aydır remisyonda olan ve bağ dokusu hastalığı tanısı almış 34 hasta ve yaş ve cinsiyet uyumu olan 30 sağlam kişi kontrol grubu olarak değerlendirilmiştir. Santral makula kalınlığı (SMK) subfoveal, nazal ve temporal 500, 1500 mikron mesafelerdeki KK, SD OKT ile ölçülmüştür.

Bulgular: Hasta grubunda ortalama SMK $(219,2 \mu \mathrm{m})$ kontrol grubuna göre $(225,5 \mu \mathrm{m})$ daha ince bulunmuştur. Ancak aradaki fark istatistiksel olarak anlamlı değildi $(P=0,2)$. Aynı zamanda ortalama KK her ölçüm noktası için hasta grubunda incelmiş olarak bulunmuştur fakat aradaki fark yine istatistiksel olarak anlamlı değildi $(P>0,05)$.

Sonuçlar: İstatistiksel olarak anlamlı olmamasına rağmen BDH'larında koroid dokusu kalınlığı incelmiş olarak bulunmuştur.

Anahtar kelimeler: Optik koherens tomografi, göz hastalıkları, bağ dokusu hastalıkları, koroidal hastalıklar, klinik çalışma

\section{Introduction}

Connective tissue diseases (CTD) comprise a broad clinical spectrum of disorders of unknown etiology, involving connective tissue of various organs and tissues and affect mostly women. The main diseases in this group, systemic lupus erythematosus, systemic sclerosis, dermatomyositis and polymyositis, mixed type (undifferentiated) connective tissue disease, Sjögren's syndrome and vasculitis, are similar to chronic autoimmune diseases. In CTD, the prognosis varies, depending on the type of disease and other rheumatologic comorbidities; while the early diagnosis is generally positive, some lethal diseases may have a rapid progression. Connective tissue disorders include a diverse group of multisystem diseases that may have ocular involvement that is occasionally sight threatening. The most common manifestations include keratoconjunctivitis sicca, anterior uveitis, and scleritis. Not only may the recognition of ocular symptoms and signs in these patients have important diagnostic and visual implications, but ocular inflammation may sometimes correlate with the severity of the systemic condition.

In particular, histological studies in patients with systemic sclerosis have demonstrated that choroidal vessels are grossly affected and present endothelial cell damage, basement membrane thickening and absence of pericytes [1], which overall can contribute to the impaired choroidal circulation shown by fundus fluorescein angiography, an invasive technique [2]. In addition, abnormal neurogenic control of choroidal vascular tone has been reported in systemic sclerosis (SSc patients). Ocular vasospasm may induce optic nerve damage, thus contributing to normal-tension glaucoma which is reported to have an increased prevalence in SSc [3]. Moreover, in patients with SSc, normal-tension glaucoma has been related to the observation of nail bed hemorrhages observed by capillaroscopy, whereas other nail fold capillary abnormalities, such as giant capillaries or avascular areas, are not related to retinal vascular changes observed in the ocular fundi [4-6]. In the early phase of the disease, these eye abnormalities are generally overlooked in a regular eye examination because they are not necessarily associated with impaired visual acuity.

The human choroid is one of the most vascularized tissues and its vascularization provides oxygenation and nutrition to the outer retina, contributes to the removal of various substances and undertakes important tasks in the secretion of growth factors [7]. The choroidal vascularization is vital to the normal structure and function of the retina. Abnormal or impaired choroidal circulation can affect the function of the photoreceptor cells, and may lead to their loss and eventual destruction [8].

The choroid has both sympathetic and parasympathetic innervations. These nerves regulate the choroid blood flow. Aside from this regulation, the choroid has an autoregulatory mechanism for its blood supply [9].

Developed in recent years, optical coherence tomography (OCT) and enhanced depth imaging (EDI) techniques have led to a better visualization of the choroid in vivo [10]. Choroid thickness (CT) measurements can be performed using spectral domain OCT and EDI techniques. These advances have led to the possibility of obtaining detailed measurements of the CT in a variety of ocular diseases [11,12].

In this study we aimed to determine the relationship between the thickness of the choroid which is a highly vascular tissue and CTD and to evaluate the predictive potential of CT measurements using spectral domain optical coherence tomography (SD OCT) with enhanced depth imaging (EDI).

\section{Material and methods}

This prospective study was conducted in accordance with the principles of the Declaration of Helsinki (1975) and approved by the institutional review board and the local ethics committee. All subjects agreed to participate in this study and each subject signed an informed consent form.

All subjects enrolled had been previously diagnosed with CTD under remission stage at least 3 month and followed by our rheumatology clinic. Subjects with CTD $(n=34)$ were selected randomly and only the right eye of each subject was examined in the study. The exclusion criteria was as follows: 1) patient 
scheduled to undergo eye surgery; 2) comorbid systemic or chronic illness; 3) comorbid ophthalmologic disease; 4) axial length more than the $24 \pm 1.0$ range and 5) refractive error greater than \pm 3.00 diopters. The control group $(n=$ 30) consisted of age- and gender-matched healthy subjects whose right eye were examined.

Detailed ophthalmological examinations were performed in all subjects. Visual acuity measurements, intraocular pressure measurements, slit lamp biomicroscopy and fundus examinations were performed to exclude co-existing diseases. The choroid and macular measurements were determined using EDI OCT (Spectralis-Ultra, $870 \mathrm{~nm}$; Heidelberg Engineering Co., Heidelberg, Germany). Only the right eye measurements of each subject were retrieved for evaluation.

\section{Enhanced-Depth-Imaging Optical Coherence Tomography}

The enhanced-depth-imaging OCT device was operated by the same experienced technician and images were taken at noon in all subjects. The choroid was imaged using the device with eye tracking and image-averaging systems, as previously described [10]. The OCT device was pushed sufficiently close to the eye to obtain an inverted image. Each section was imaged using eye tracking, and $100 \mathrm{~B}$-scans were averaged to improve the signal-to-noise ratio (SNR). Six-millimeter horizontal and vertical images that included the fovea were obtained. The choroidal thickness was defined as the vertical distance between the RPE and the choroidal-scleral interface. Two examiners, who were blinded to the study design, manually measured the choroidal thickness separately at 5 points. Vertical line scans were obtained to determine the central macular thickness (CMT) and subfoveal choroidal thickness (SFCT). The CT at nasal (N) and temporal (T) distances of 500 $\mu \mathrm{m}$ (N500 and T500, respectively) and $1500 \mu \mathrm{m}$ (N500 and T1500, respectively) from the central fovea were determined using this technique (Figure 1).

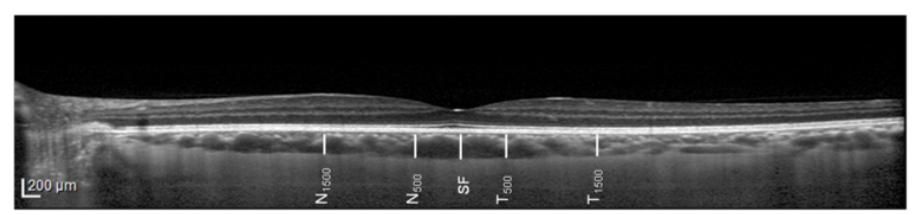

Figure 1. Demonstrative images for choroidal thickness measurements on EDI-OCT. Central macular thickness (CMT) and subfoveal choroidal thickness (SFCT).The CT at nasal (N) and temporal (T) distances of $500 \mu \mathrm{m}$ (N500 and T500, respectively) and $1500 \mu \mathrm{m}$ (N500 and T1500, respectively) from the central fovea were determined using this technique.

\section{Statistical analysis}

Data analysis was performed using the SPSS for Windows 15.0 software package. The data are expressed using percentage values, or group mean and standard deviation values. The interexaminer reproducibility values were evaluated based on the intraclass correlation coefficients (ICCs). The t-test was used to compare continuous variables with normal distribution, and Mann-Whitney's U-test was used to compare non- normally distributed continuous variables. The chi-square test was used for the comparison of discrete variables. Statistical significance was accepted when $\mathrm{P}$ value $<0.05$.

\section{Results}

Thirty four subjects diagnosed with CTD from rheumatology clinic were included. The control group consisted of 30 subjects without systemic or localized diseases. The demographic characteristics of the subjects are shown in Table 1. There were no statistically significant differences between the CTD and control groups in terms of age distribution $(P=0.912)$. There were no statistically significant differences between the CTD and control groups in terms of gender distribution ( $P=$ $0.537) .23$ subjects were females (67.35\%) and 11 were males (32.35\%). The average age of the subjects were $47.7 \pm 19.2$ years and for controls were $47.14 \pm 17.5$.

Table 1. Baseline characteristics of the study groups

\begin{tabular}{|l|c|c|c|}
\hline & CTD & Controls & $P$ \\
\hline Age (mean \pm SD), years & $47.75 \pm 19.2$ & $47.14 \pm 17.5$ & 0.912 \\
\hline Gender (female/male) & $23 / 11$ & $20 / 10$ & 0.537 \\
\hline
\end{tabular}

Among the 34 subjects in the CTD group, 8 (23.52\%) had Sjögren's syndrome, 9 (26.47\%) had rheumatoid arthritis, $8(23.52 \%)$ had systemic sclerosis, $5(14.70 \%)$ could not be distinguished (undifferentiated type), 2 (5.88\%) had Bechet's disease and 2 (5.88\%) had systemic lupus erythematosus.

When the mean CMT was compared, the mean CMT of CTD subjects $(219.2 \mu \mathrm{m})$ was thinner compared with the control group $(225.5 \mu \mathrm{m})$, but this difference was not statistically significant $(P=0.239)$. The mean subfoveal CT (CTD: $278.5 \mu \mathrm{m}$, control: $299.0 \mu \mathrm{m} ; \mathrm{P}=0.656$ ); N500 (CTD: $255.7 \mu \mathrm{m}$, control: $273.2 \mu \mathrm{m} ; \mathrm{P}=0.514)$; N1500 (CTD: $232.1 \mu \mathrm{m}$, control: $233.5 \mu \mathrm{m}$; $\mathrm{P}=0.954) ; \mathrm{T} 500$ (CTD: $248.6 \mu \mathrm{m}$, control: $278 \mu \mathrm{m} ; \mathrm{P}=0.267$ ); and T1500 (CTD: $251.6 \mu \mathrm{m}$, control: $274.6 \mu \mathrm{m} ; \mathrm{P}=0.312$ ) were not significantly different. Central foveal and choroidal thickness measurement comparisons between patients with CTD and healthy controls are shown in Table 2. Although no statistically significant differences were found in all parameters, the CTD group tended to have a thinner CMT and decreased CT at all points of measurement.

Table 2. Central foveal and choroidal thickness measurement comparisons between patients with CTD and healthy controls

\begin{tabular}{|l|c|c|c|}
\hline & CTD & Control & $P$ \\
\hline CFT & $219.2 \pm 16.6$ & $225.5 \pm 18.8$ & 0.239 \\
\hline CT-Subfoveal & $278.5 \pm 84.0$ & $291 \pm 100.8$ & 0.656 \\
\hline CT-Nasal500 & $255.7 \pm 91.7$ & $273.2 \pm 89.7$ & 0.514 \\
\hline CT-Nasal1500 & $232.1 \pm 90.3$ & $233.5 \pm 74.8$ & 0.954 \\
\hline CT-Temporal500 & $248.6 \pm 91.4$ & $278.0 \pm 86.5$ & 0.267 \\
\hline CT-Temporal1500 & $251.6 \pm 84.0$ & $274.6 \pm 69.9$ & 0.312 \\
\hline
\end{tabular}




\section{Discussion}

With advances in OCT technology and software, detailed measurements of the choroid have become possible [13]. CT can be affected by various parameters, such as age, axial length and refractive errors $[14,15]$. Further, it has been shown that CT undergoes diurnal changes $[10,16]$. The choroid is affected by blood pressure and intraocular pressure changes, and exhibits an autoregulatory mechanism $[17,18]$. This rich vascular structure may affect the CT. Tanabe et al showed a significant correlation between choroid vein diameter and the thickness of the choroid [19]. Vance et al reported that phosphodiesterase-5 inhibitors, such as sildenafil citrate, determine an increase in CT due to their smooth muscle relaxant effects [20].

First researches tried to find out any correlation between choroidal thickness and possible microcirculatuar diseases like diabetes or hypercholesterolemia. In a study by Wong et al, choroidal thickness was found to be thicker in the presence of hypercholesterolemia [21]. This study was limited by the cross-sectional study design, subjects were Chinese; hence, the results of this study could not address the issue of any ethnic differences in the choroidal thickness. Regatieri et al [22] found that the choroid was thinner among subjects with diabetic retinopathy. Diabetes, being another microcirculatuar changes, may affect the choroid. In another interesting study Ayton et al. have shown choroidal thickness profiles in patients with retinitis pigmentosa [23]. Patients with retinitis pigmentosa had a thinner choroid than controls. Patients with poorer visual acuity or longer duration of symptoms tended to have thinner choroids.

Although no statistically significant differences were found in our study, the CTD group tended to have a thinner CMT and decreased $\mathrm{CT}$ at all points of measurement. A study by Ingegnoli et al in patients with systemic sclerosis evaluated the same parameters [24]. They have shown that CT decreased significantly at all points examined. A reduction in macular thickness was also found, but this difference was not considered statistically significant, which is consistent with our results. In current study, we evaluated patients diagnosed with CTD under remission stage at our rheumatology clinic. In our particular comment the difference depends on the fact that our cases were under remission. Despite the lack of statistical difference, there was a clear tendency for decrease in CT in patients with CTD. In general, however, CT measurements may differ depending on the technique or device used.

The macula is the most important part of the retina in terms of choroidal vascular perfusion because the macula lacks additional blood supply sources. In our study, we did not find statistically significant differences in CMT, but a decreasing trend in central foveal thickness was noted, similar to the results of the study by Ingegnoli et al Impaired choroid circulation in systemic CTD has been confirmed earlier by studies that used fluorescein angiography $[1,25]$. Tailor et al found a reduction in the internal arteriolar elastic membrane in systemic sclerosis and argued that this could be linked to a lack of nerve support in the choroid and retinal vessels [26].

The choroid may behave differently in different diseases. Ankylosing spondylitis is a spondyloarthropathy that is classically considered outside the CTD spectrum. However, eye involvement occurs often and seems to be associated with the presence of HLA B27. Kola et al investigated posterior segment findings in patients with ankylosing spondylitis and emphasized that there were no significant differences between the patients with ankylosing spondylitis and the healthy group. The authors also noted that mean CT was higher in patients with ankylosing spondylitis compared with the healthy controls [27].

Duru at al investigated the choroidal thickness in 146 rheumatoid arthritis patients in the active phase [28]. This study showed that choroidal tissue was significantly thinner in patients with RA when compared with healthy controls. Altınkaynak at al evaluated choroidal thickness in patients with SLE [29] and found reduced choroidal thickness in the active phase of the disease. Weal so found thinner choroid in our patients, but the difference was not statistically significant. Our patients were all in the convalescence phase of the diseases and during this phase, choroidal involvement might have returned to normal. In this study, our primary goal was to make a comparison of choroidal thickness among various CTD in one study.

Limitations of this study include the relatively small number of patients. Moreover, there is a high variability of choroidal thickness measurements in normal subjects. We attempted to account for age and refractive error, which are the two most important parameters likely to influence choroidal thickness. A circadian influence was minimized by measuring patients only in the noon. However, other factors potentially influencing choroidal thickness measures, such as ocular perfusion pressure or corticosteroids and aldosterone levels, were not monitored. On the other hand, study groups were united under the same title but consisted of from different diseases, it could be effect the results.

As a result, we attribute the decreased CMT and CT in CTD to the reduction of choroidal perfusion. With the development of OCT imaging and software technologies, the CMT and CT measurements will emerge as predictive parameters for many systemic diseases. Our findings, indicating lower values for these parameters, even if we did not reach statistical significance, suggest that the measured variables may have diagnostic value in CTD. 


\section{Declaration of conflicting interests}

The authors declared no conflicts of interest with respect to the authorship and/or publication of this article.

\section{Funding}

The authors received no financial support for the research and/or authorship of this article.

\section{References}

1. Farkas TG, Sylvester V, Archer D. The choroidopathy of progressive systemic sclerosis (scleroderma). Am J Ophthalmol 1972; 74: 875-86.

2. Serup L, Serup J, Hagdrup H. Fundus fluorescein angiography in generalized scleroderma. Ophthalmic Res 1987; 19: 303-8.

3. Allanore $Y$, Parc C, Monnet D, Brézin AP, Kahan A. Increased prevalence of ocular glaucomatous abnormalities in systemic sclerosis. Ann Rheum Dis 2004; 63: 1276-8.

4. Božić $M$, Senćanić $P H$, Spahić $G$, et al. Is nail fold capillaroscopy useful in normotensive and primary open angle glaucoma? A pilot study. Curr Eye Res 2010; 35: 1099-104.

5. Park HY, Park SH, Oh YS, Park CK. Nail bed hemorrhage: a clinical marker of optic disc hemorrhage in patients with glaucoma. Arch Ophthalmol 2011; 129: 1299-304.

6. Ushiyama O, Ushiyama K, Yamada $\mathrm{T}$, et al. Retinal findings in systemic sclerosis: a comparison with nailfold capillaroscopic patterns. Ann Rheum Dis 2003; 62: 204-7.

7. Parver LM. Temperature modulating action of choroidal blood flow. Eye 1991; 5: 181-5.

8. Cao J, McLeod S, Merges CA, et al. Choriocapillaris degeneration and related pathologic changes in human diabetic eyes. Arch Ophthalmol1998; 116: 589-97.

9. Nickla DL, Wallman J. The multifunctional choroid. Prog Retin Eye Res. 2010; 29: 144-68.

10. Spaide RF, Koizumi H, Pozzoni MC. Enhanced depth imaging spectral-domain optical coherence tomography. Am J Ophthalmol 2008; 146: 496-500.

11. Ikuno Y, Kawaguchi $K$, Nouchi T, et al. Choroidal thickness in healthy Japanese subjects. Invest Ophthalmol Vis Sci 2010; 51: 2173-6.

12. Manjunath V, Taha M, Fujimoto JG et al. Choroidal thickness in normal eyes measured using Cirrus HD optical coherence tomography. Am J Ophthalmol 2010; 150: 325-9.

13. Margolis R, Spaide RF. A pilot study of enhanced depth imaging optical coherence tomography of the choroid in normal eyes. Am J Ophthalmol 2009; 147: 811-5.

14. Ikuno Y, Kawaguchi K, Nouchi T, Yasuno Y. Choroidal thickness in healthy Japanese subjects. Invest Ophthalmol Vis Sci 2010; 51: 2173-6.
15. Agawa T, Miura M, IkunoY, et al.Choroidal thickness measurement in healthy Japanese subjects by three-dimensional highpenetration optical coherence tomography. Graefes Arch 2011; 249: 1485-92.

16. Brown JS, Flitcroft DI, Ying GS, et al. In vivo human choroidal thickness measurements: evidence for diurnal fluctuations. Invest Ophthalmol Vis Sci 2009; 50: 5-12.

17. Reiner A, Li C, Del Mar N, Fitzgerald ME. Choroidal blood flow compensation in rats for arterial blood pressure decreases is neuronal nitric oxide-dependent but compensation for arterial blood pressure increases is not. Exp Eye Res 2010; 90: 734-41.

18. Kiel JW. Choroidal myogenic autoregulation and intraocular pressure. Exp Eye Res 1994; 58: 529-43.

19. Tanabe H, Ito $\mathrm{Y}$, Iguchi $\mathrm{Y}$, Ozawa S, Ishikawa K, Terasaki H. Correlation between cross-sectional shape of choroidal veins and choroidal thickness. Jpn J Ophthalmol 2011; 55: 614-9.

20. Vance SK, Imamura Y, Freund KB. The effects of sildenafil citrate on choroidal thickness as determined by enhanced depth imaging optical coherence tomography. Retina 2011; 31: 332-5.

21. Wong IY, Wong RL, Zhao P, Lai WW. Choroidal thickness in relation to hypercholesterolemia on enhanced depth imaging optical coherence tomography. Retina 2013; 33: 423-8.

22. Regatieri CV, Branchini L, Carmody J, et al. Choroidal thickness in patients with diabetic retinopathy analyzed by spectral-domain optical coherence tomography. Retina 2012; 32: 563-8.

23. Ayton LN, Guymer RH, Luu CD. Choroidal thickness profiles in retinitis pigmentosa. Clin Experiment Ophthalmol 2013; 41:396-403.

24. Ingegnoli F, Gualtierotti R, Pierro L, et al. ACUTE study group; ACUTE study group. Choroidal impairment and macular thinning in patients with systemic sclerosis: the acute study. Microvasc Res 2015; 97: 31-6.

25. Grennan DM, Forrester J. Involvement of the eye in SLE and scleroderma. A study using fluorescein angiography in addition to clinical ophthalmic assessment. Ann Rheum Dis 1977; 36: 152-6.

26. Tailor R, Gupta A, Herrick A, Kwartz J. Ocular manifestations of scleroderma. Surv Ophthalmol 2009; 54: 292-304.

27. Kola M, Kalkisim A, Karkucak M, et al. Evaluation of choroidal thickness in ankylosing spondylitis using optical coherence tomography. Ocul Immunol Inflamm 2014; 22: 43-8.

28. Duru N, Altinkaynak $\mathrm{H}$, Erten Ş, et al. Thinning of choroidal thickness in patients with rheumatoid arthritis unrelated to disease activity. Ocul Immunol Inflamm 2016; 24: 246-53.

29. Altinkaynak H, Duru N, Uysal BS, et al. Choroidal thickness in patients with systemic lupus erythematosus analyzed by spectral-domain optical coherence tomography. Ocul Immunol Inflamm 2015; 8: 1-7. 